DOI: $10.17951 / 1 r p .2020 .39 .1 .233-250$

\begin{abstract}
ANDRZEJ Felchner
Zakład Historii Oświaty i Wychowania oraz Teorii Kształcenia, Instytut Nauk Pedagogicznych, Wydział Nauk Społecznych Uniwersytet Jana Kochanowskiego w Kielcach

Filia w Piotrkowie Trybunalskim

ORCID - 0000000223185234
\end{abstract}

\title{
WPŁYW UWARUNKOWAŃ SPOŁECZNYCH, EKONOMICZNYCH I ZDROWOTNYCH \\ NA WYCHOWANIE UCZNIÓW \\ W OKRESIE II RZECZYPOSPOLITEJ \\ NA PRZYKŁADZIE PIOTRKOWA TRYBUNALSKIEGO \\ I POWIATU PIOTRKOWSKIEGO
}

\begin{abstract}
Streszczenie: $\mathrm{W}$ wyniku splotu szeregu różnych czynników, w tym aktywnej działalności całych pokoleń Polaków, jesienią w 1918 roku Polska odzyskała niepodległość. Sytuacja, zwłaszcza gospodarcza i zdrowotna, była jednak bardzo zła. W latach 1918-1939 następowały korzystne zmiany. Mimo to przez ten cały okres zwłaszcza sytuacja mieszkaniowa i żywieniowa większości społeczeństwa nie była zadowalająca. Szczególnie niekorzystnie oddziaływała ona na dzieci i młodzież. Dobrym przykładem jest tu Piotrków Trybunalski wraz z powiatem. W samym mieście większość mieszkańców żyła w jedno-, dwupokojowych ciasnych mieszkaniach, na ogół pozbawionych dostępu do sieci wodno-kanalizacyjnej, a większość najmłodszych była źle, niewłaściwie odżywiana, a nawet często niedożywiona. Jeszcze gorsza sytuacja pod tym względem była na terenie powiatu piotrkowskiego, zwłaszcza na wsi. Mówiąc o oświacie i wychowaniu dzieci oraz młodzieży w Polsce, w okresie między I a II wojną światową, należy na te trudne, ale ważne problemy zwracać dużą uwagę.
\end{abstract}

Słowa kluczowe: Polska 1918-1939, Piotrków Trybunalski i powiat piotrkowski, wychowanie, dzieci, zdrowie

Lata 1918-1939 są niezwykle ważne w dziejach naszego narodu. Po blisko półtora wieku niewoli uzyskaliśmy możliwość budowy własnego państwa. Jego odbudowa oraz rozwój były jednak zdeterminowane wieloma niekorzystnymi faktami. Nie 
chodzi tu tylko o niezbędne ujednolicenie ustroju gospodarczego całego państwa z ziem rozdzielonych jeszcze w XVIII wieku, w zupełnie innej sytuacji społeczno-gospodarczej, panującej w początkach XX wieku. Trudności z tego wynikające, a także konieczność zbudowania jednolitych systemów we wszystkich dziedzinach życia polskiego społeczeństwa, były dodatkowo pogłębione przez inne, niezależne od nas okoliczności. Pierwsze lata istnienia II Rzeczypospolitej - do połowy 1921 to w większości zwycięskie walki o niepodległość i granice. Przyniosły one jednak dalsze straty we wszystkich dziedzinach życia społecznego czy gospodarczego, wyczerpały zapasy materiałowe i żywnościowe, nie mówiąc o stratach w infrastrukturze oraz bardzo bolesnych - osobowych, demograficznych. Kilka następnych lat to postępujący kryzys monetarny, który doprowadził do hiperinflacji, grożącej załamaniem się całego państwa. Dopiero polityka gospodarcza rządu Władysława Grabskiego i wprowadzenie w 1924 roku (bez dodatkowego zadłużania zagranicznego) nowej waluty - złotówki, pomogło ustabilizować sytuację․ Kilka następnych lat - do wybuchu wielkiego ogólnoświatowego kryzysu w 1929 roku - to okres względnego rozwoju gospodarczego. Na te lata przypada jednak kryzys polityczny i objęcie władzy przez obóz polityczny Józefa Piłsudskiego drogą zamachu stanu przeprowadzonego w maju 1926 roku. To oraz różne inne perturbacje z gospodarczą wojną polsko-niemiecką na czele wpłynęły na społeczeństwo zarówno negatywnie, jak i pozytywnie, przyczyniły się choćby do szybszej budowy Gdyni i jedynego naszego portu, który krótko przed wojną stał się największym na Bałtyku². Kilka lat

${ }^{1} \mathrm{~W}$ swoim expose sejmowym wygłoszonym na połączonym posiedzeniu sejmu i senatu 20 grudnia 1923 roku Władysław Grabski stwierdził: „Doszliśmy [...] do takiego stanu, że żaden postęp w żadnej dziedzinie, nawet w szkolnictwie, nie mówiąc o reformie rolnej, lub udoskonaleniach socjalnych, stają się niemożliwe [...] rząd stawia sobie za zadanie takie ogniskowanie wysiłków własnych społeczeństwa, aby były one w stanie wyprowadzić nas z dzisiejszego ostrego stanu krytycznego [...]. Z jednej strony zwiększać będzie świadczenia podatkowe i dążyć do wzmożenia dochodów zwyczajnych, z drugiej strony do wzmocnienia dochodów nadzwyczajnych [...]", cytat za: Wiek XX w źródłach. Wybór tekstów źródłowych z propozycjami metodycznymi dla nauczycieli historii, studentów i uczniów, 1998, opr. M. Sobańska-Bondaruk, S.B. Lenard. Warszawa, s. 157-158. O wysokości inflacji świadczą przytoczone dane w komentarzu do expose: 31 grudnia 1920 roku 1 dolar USA kosztował oficjalnie 590 polskich marek, 31 grudnia 1923 - 1502000 marek, a tuż przed wymianą pieniędzy 15 kwietnia 1924 roku - 9300 000, tamże. Bardzo obrazowo przejście od gospodarki wojennej lat 1919-1921 do reformy W. Grabskiego pokazał graficznie też J. Skodlarski, 2000, Zarys historii gospodarczej Polski. Warszawa, Łódź, s. 243 - w 1919 roku za określoną sumę marek polskich można było kupić ubranie wraz z bielizną, płaszczem i butami, w 1921 roku za tą samą kwotę - tylko buty i skarpetki, a w 1923 - pudełko zapałek.

${ }^{2}$ J. Szpak, 1997, Historia gospodarcza powszechna. Warszawa, s. 179. Szpak nazywa okres drugiej połowy lat 20. „sztuczną prosperity”, która doprowadziła do wybuchu ogólnoświatowego kryzysu. Polsko-niemiecka wojna gospodarcza, podczas której nasz zachodni sąsiad starał się wymóc przede wszystkim pewne polityczne zyski, a nawet korekty granic, miała miejsce w latach 1925-1934. Osłabiła nieco polską gospodarkę, ale też wymusiła różne pozytywne gospodarcze działania i w dużym 
załamania rozwoju gospodarczego na całym świecie rozpoczęło się w pamiętany do dziś czarny czwartek 24 października 1929 roku na nowojorskiej giełdzie. Spadek produkcji, duże osłabienie gospodarki, czego ilustracją było obniżenie wskaźników ekonomicznych w większości krajów o ponad 50\%, wyjątkowo boleśnie dotknęło słabą polską gospodarkę, głównie rolnictwo. Znalazło to też odbicie w drastycznie pogarszającej się sytuacji materialnej większości polskich rodzin, nie tylko najuboższych. Ostatnie kilka lat niepodległości to w kierowanej przez wicepremiera Eugeniusza Kwiatkowskiego gospodarce etatyzm, interwencjonizm państwowy, nakręcanie koniunktury, budowa Centralnego Okręgu Przemysłowego i dalsza rozbudowa dumy Polski - miasta i portu w Gdyni. To równocześnie narastające niebezpieczeństwa agresji ze strony naszych wschodnich i zachodnich sąsiadów. Totalitarne rządy Stalina i Hitlera stawały się coraz większym zagrożeniem dla istnienia z takim trudem odbudowywanej i rozbudowywanej II Rzeczypospolitej³.

stopniu uniezależniła ją od sąsiada, czego symbolem stała się właśnie Gdynia, która z niewielkiej wioski w kilkanaście lat przekształciła się w ponad stutysięczne miasto, J. Skodlarski, s. 247-265. Interesująco piszą też na ten temat J. Tomaszewski, Z. Landau, 2005, Polska w Europie i świecie 1918-1939. Warszawa, pokazując zachodzące przemiany na tle gospodarki światowej i porównując do poziomu gospodarki sprzed I wojny światowej. Według oficjalnych statystyk w II RP w 1930 roku łącznie eksport i import drogą lądową wynosił 11155 tys. ton, a drogą morską 11338 tys. ton, z czego większość jeszcze przez Wolne Miasto Gdańsk - 8063 tys. ton. W 1938 roku drogą lądową wyniósł tylko 4212 tys. ton, a morską 14695 tys. ton, z czego przez Gdynię 8713 tys. ton. Nośność dźwigów w porcie gdyńskim zwiększyła się w latach 1928-1938 ponad dziesięć razy: z 34,4 ton do 350,7, a sześciokrotnie liczba statków, które do niego wpłynęły. Pod tym względem tuż przed wojną Gdynia wysunęła się przed dotychczas dominujący na Bałtyku Gdańsk, Mały Rocznik Statystyczny Polski wrzesień 1939-czerwiec 1941, 1941, Londyn, s. 73, tab. 4; s. 88, tab. 11, s. 89, tab. 12. Zawarte tam dane sprzed września 1939 roku pochodzą z przedwojennych roczników statystycznych.

${ }^{3}$ Literatura na ten temat jest bardzo bogata. Do ciekawych syntez wydanych w Polsce po 1990 roku (po zniesieniu cenzury) można na przykład zaliczyć oprócz już cytowanych powyżej monografii J. Skodlarskiego, J. Szpaka oraz J. Tomaszewskiego i Z. Landaua - nie mówiąc o podręcznikach i bardzo licznych opracowaniach z historii dwudziestowiecznej Polski - podręcznik R. Camerona, Historia gospodarcza świata. Od paleolitu do czasów najnowszych, wyd. II, Warszawa 1997. Mimo ożywienia koniunktury po kryzysie, rozwoju inwestycji (między innymi w przemysł zbrojeniowy), o słabości polskiej gospodarki, dystansie w tym zakresie do naszych sąsiadów i potencjalnych sojuszników, świadczą wydatki na uzbrojenie z lat 30. W 1932 roku Niemcy, skrępowane jeszcze wówczas postanowieniami traktatu wersalskiego, wydały na zbrojenia 162 miliony ówczesnych USD, ZSRR 722, Wielka Brytania 512, Francja 498, a Polska 151. W 1938 roku III Rzesza przeznaczyła na te cele aż 7415 milionów USD, ZSRR 5429, Wielka Brytania 1863, Francja 919, a Polska 253, K. Popiński, 2010, Finansowe uwarunkowania rozwoju polskiego potencjału militarnego $w$ latach 1936-1939. W: T. Głowiński i K. Popiński (red.), Gospodarka i społeczeństwo a wojskowość na ziemiach polskich. Wrocław, s. 225. Warto też przypomnieć, iż w tym samym czasie -2 grudnia 1938 roku - ówczesny wicepremier i minister skarbu Eugeniusz Kwiatkowski w sejmowym przemówieniu przedstawił piętnastoletni plan gospodarczego rozwoju II RP, podzielony na pięć trzyletnich okresów: 1) rozbudowa potencjału obronnego, 2) rozwój komunikacji, 3) udoskonalenie 
Takie skrótowe $\mathrm{z}$ konieczności przypomnienie pewnych podstawowych danych gospodarczych Polski z okresu między I a II wojną światową jest konieczne przy omawianiu różnych uwarunkowań wpływających na wychowanie uczniów w tym okresie. Słabości bądź sukcesy szeroko pojętej oświaty, wychowania dzieci i młodzieży, mają swoje podłoże w sytuacji gospodarczej, w zamożności lub biedzie wszystkich warstw społecznych. Można tu przypomnieć choćby podręczniki z biomedycznych podstaw kształcenia i wychowania, $\mathrm{z}$ którego korzystają studenci pedagogiki ${ }^{4}$ W każdym bez wyjątku opracowaniu na te tematy podkreśla się rolę środowiska wychowawczego z rodziną na czele. Wiele mówi się też o prawidłowym żywieniu, możliwości spokojnego uczenia się i właściwym wypoczynku dzieci i młodzieży, co w dużej mierze wypływa $\mathrm{z}$ sytuacji materialnej. Jeśli spojrzymy na te i podobne kwestie przez pryzmat przedwojennych realiów, to można też stwierdzić, że wiele trudności i nieprawidłowości, było przeważnie niezależnych od rodziców czy nauczycieli. Wynikały one w wielu wypadkach z zastałej sytuacji gospodarczo-społecznej, wieloletnich zaniedbań, często mających swój rodowód w celowej polityce poszczególnych zaborców - jak choćby niewprowadzenie w zaborze rosyjskim, a także w całym państwie carów, obowiązku i przymusu szkolnego. Rodzice, szczególnie na wsi czy w małych miasteczkach, niezamożni, a nawet biedni, sami często analfabeci, nie zawsze rozumieli potrzeby edukacyjne swoich dzieci i nie dążyli do zdobycia przez nich jak najlepszego wykształcenia. Warto podkreślić - krótkie okresy względnego rozwoju przedzielane są latami niekorzystnymi dla gospodarki i polityki społecznej. Te ostatnie są większe niż czasy spokojnej działalności na rzecz rozwoju kraju, w tym i oświaty. Widać to dziś doskonale $\mathrm{z}$ dystansu prawie stulecia, które dzieli nas od tamtych lat sprzed II wojny światowej.

II Rzeczypospolita to państwo wielu narodów, kultur, religii. Przeważali Polacy - około dwie trzecie, ale ponadto, zwłaszcza w wielu małych miasteczkach i w Warszawie - bardzo liczna była społeczność żydowska. Na wschodzie Ukraińcy, Białorusini, województwa zachodnie i w niektórych innych regionach - mniejszość niemiecka. To kraj w wielu wypadkach pełen kontrastów. Z jednej strony Wielkopolska z rozwiniętym rolnictwem i Poznaniem - miejscem międzynarodowych targów, a z drugiej Polesie, tereny bardziej przypominające początek XIX wieku niż XX.

oświaty i rolnictwa, 4) urbanizacja i uprzemysłowienie, 5) zatarcie różnic między tzw. Polską A i B, fragmenty tekstu przemówienia W: Wiek XX w źródłach, s. 177-178.

${ }^{4}$ Bardzo popularnym jest opracowanie zbiorowe: B. Wojnarowska, A. Kowalewska, Z. Izdebski, K. Komosińska, 2010, Biomedyczne podstawy kształcenia i wychowania. Podręcznik akademicki. Warszawa, dodruk w 2012. Bardziej psychologiczne podejście reprezentuje monografia: Z. Włodarski, A. Hankała, 2004, Nauczanie i wychowanie jako stymulacja rozwoju człowieka. Podręcznik dla studentów szkół pedagogicznych i nauczycieli. Warszawa-Kraków. 
Uprzemysłowiony Śląsk czy Zagłębie i województwo nowogródzkie, gdzie ludność żadnego z dziesięciu miast, $\mathrm{w}$ większości małych miasteczek, nie przekroczyła do września 1939 roku liczby 25 tys. mieszkańców. Rozwijająca się stolica ze szkołami wyższymi, eksperymentalnym studiem telewizyjnym, lotniskiem i zelektryfikowanym węzłem kolejowym oraz małe, zaniedbane, w większości drewniane, kresowe miasteczka i wioski, w województwach: wileńskim, nowogródzkim, poleskim, do których trudno było czymkolwiek dojechać. Budowana od podstaw nowoczesna Gdynia - „okno na świat” Rzeczypospolitej i zagubione we wschodnich Karpatach przysiółki huculskie. Takich porównań można dorzucić jeszcze bardzo dużo ${ }^{5}$. Dlatego też trudno z jednej strony uznać Piotrków Trybunalski za reprezentatywny, typowy w skali wszystkich ówczesnych polskich miast i miasteczek. Był jednym z większych powiatowych ośrodków. Podobnie jak kilka innych - Chełm, Kalisz, Łomża, Płock, Siedlce czy Suwałki - utracił status stolicy guberni, a więc wyższej jednostki administracyjnej. Była to swego rodzaju degradacja administracyjna - ale z drugiej strony urzędy gubernialne były obsadzane głównie przez Rosjan. To jeden z istotnych elementów rusyfikacji polskich ziem. Piotrków Trybunalski uniknął zniszczeń w czasie I wojny światowej i podczas toczących się walk o niepodległość. Był ważnym węzłem komunikacyjnym z dość liczną grupą kolejarzy, leżał stosunkowo blisko granicy państwowej z Niemcami. Należy jednak pamiętać, że w II Rzeczypospolitej tylko jedno województwo - lubelskie - nie miało obszarów granicznych z innym państwem. W mieście pracowały różnorodne fabryki - huty szkła, zakłady przemysłu włókienniczego czy drzewnego, a także liczni rzemieślnicy i kupcy. W okresie międzywojennym podwoiła się liczebność robotników, mimo wielkiego kryzysu i okresowego zamykania niektórych zakładów. Często można było spotkać na ulicy żołnierzy, głównie z 25 pułku piechoty, bo stacjonował tu spory garnizon wojskowy, a z drugiej strony - samych takich jednostek - piechoty, kawalerii i artylerii - było ponad 150. Było i jest tu stare miasto $z$ istniejącym do dziś zamkiem zbudowanym na polecenia Zygmunta I Starego oraz z kilkoma zabytkowymi kościołami z XIV-XVIII wieku, szczęśliwie zachowanymi mimo obydwu wojen światowych. Można więc jednak uznać Piotrków Trybunalski za jedno $\mathrm{z}$ wielu miast powiatowych, stosunkowo duże w tej grupie i reprezentatywne, zwłaszcza wśród ośrodków miejskich centralnej Polski czy ziem dawnej tak zwanej Kongresówki. Ówczesna zabudowa to centrum z wielkomiejskimi kamienicami i wiejskie przedmieścia włączone do miasta w latach I wojny światowej, gdzie do 1939 roku nie dotarła nawet elektryczność. Ludność - jak w wielu innych polskich miastach tamtych lat, to Polacy, ale też i około $20 \%$ mieszkańców należało do

${ }^{5}$ Bardzo ciekawe pod tym względem dane, ukazujące wspomniane różnice, zawiera cytowany już Mały Rocznik Statystyczny Polski. 
gminy żydowskiej. Było również trochę mniejszości niemieckiej i przedstawicieli innych narodowości. Rosjanie, dość liczni przed wybuchem I wojny światowej, w większości opuścili miasto jeszcze jesienią w 1914 roku. W omówieniu stolicy powiatu należy też wspomnieć o sytuacji na terenie tej dość rozległej piotrkowskiej jednostki administracyjnej. Były tam też dwa niewielkie ówcześnie miasta. Jedno z nich, Bełchatów, po wojnie dzięki złożom węgla brunatnego i elektrowni przekształciło się w spory ośrodek, zostając stolicą powiatu o zbliżonej do Piotrkowa liczbie mieszkańców. Drugie - Sulejów - nie zwiększyło swojej rangi małego lokalnego centrum, zwłaszcza, że poniosło dotkliwe straty w czasie II wojny światowej. Okoliczne wsie były dość zaniedbane. Ostatni z przedwojennych starostów piotrkowskich w marcu 1939 roku podkreślał, że mimo wieloletnich starań władz $\mathrm{w}$ wielu wioskach brakowało odpowiednich urządzeń sanitarnych: studni z czystą wodą, zgodnych z przepisami ustępów czy śmietników ${ }^{6}$.

Na Piotrków Trybunalski lat 1918-1939 można spojrzeć z różnych stron, analizować wiele istotnych kwestii. Miasto zmieniało się, bowiem mimo różnorodnych trudności rozbudowywało, unowocześniało, a jego ludność przed wrześniem 1939 roku wyraźnie przekroczyła liczbę 50 tys. Jedną z najważniejszych spraw jest właściwy rozwój społeczeństwa, zwłaszcza jego najmłodszych członków dzieci oraz młodzieży. Jakie warunki, możliwości działania miały ówczesne piotrkowskie rodziny? Wiadomo od dawna, że dom rodzinny, panujące tam relacje interpersonalne, warunki bytowe wywierają przemożny wpływ na prawidłowy rozwój dziecka. „[...] Rodzina wyróżnia się nie tylko pierwszeństwem oddziaływania. W niej kształtują się silne więzi emocjonalne (z rodzicami, dziadkami, rodzeństwem), decydujące o ważnym poczuciu przynależności. Dzięki rodzinie dziecko nie czuje się samotne. W rodzinie ma miejsce zaspokajania podstawowych potrzeb dziecka [...]”7. Barbara Wojnarowska dodawała „[...] Dom rodzinny jest siedliskiem, w którym „tworzone” jest zdrowie. Rodzice są pierwszymi i najważniejszymi nauczycielami zdrowia dzieci. Procesowi wychowania towarzyszy socjalizacja zdrowotna. Polega ona na kształtowaniu, w interakcji z rodzicami i innymi członkami rodziny, umiejętności i zachowań sprzyjających dobremu samopoczuciu i ochronie zdrowia $[\ldots]^{\prime \prime}$.

${ }^{6}$ Szerzej: Dzieje Piotrkowa Trybunalskiego, 1989, pod red. B. Baranowskiego. Łódź, s. 393-503. Na temat historii miasta w latach 1914-1918 pisał A. Piasta, 2007, Piotrków Trybunalski w latach pierwszej wojny światowej, Piotrków Trybunalski. Odsyłam też do własnej monografii, gdzie zawarto wiele danych obrazujących omawiane zagadnienia: A. Felchner, 2006, Zdrowie i zdrowotność Piotrkowian. Z problematyki zdrowotności mieszkańców Piotrkowa Trybunalskiego i powiatu piotrkowskiego na tle całego kraju (od końca lat 20-tych do początków 70-tych XX wieku). Wrocław.

7 Z. Włodarski, A. Hankała, s. 157.

${ }^{8}$ B. Wojnarowska i in., Biomedyczne podstawy..., dz. cyt., s. 233. 
Przytoczone powyżej wypowiedzi można skonfrontować z sytuacjami, jakie występowały w tym zakresie w polskim społeczeństwie w okresie międzywojennym na przykładzie Piotrkowa Trybunalskiego. Jak wspomniano, trudno o jakieś uśrednianie, można jednak stwierdzić, że to miasto było dość reprezentatywne dla podobnych, powiatowych, centrów administracyjnych, gospodarczych. Pojawiały się tu problemy zbliżone do występujących we wszystkich takich ośrodkach: trudne warunki ekonomiczne, bytowe, zdrowotne. Jednymi z takich najważniejszych czynników sprzyjających rozwojowi uczniów bez względu na wiek jest możliwość posiadania odpowiednich warunków mieszkaniowych. Dla właściwego kształcenia i wychowania niezbędne jest posiadanie przez nich, jeśli nie odrębnego pokoju, to przynajmniej stałej powierzchni, unikanie stresów, możliwość zachowania choćby minimum intymności. Odgrywa to niebagatelną rolę nie tylko w procesie kształcenia, ale i wychowania. Należy więc ukazać, jak ta sytuacja wyglądała w przedwojennym Piotrkowie Trybunalskim. Dzięki spisom powszechnym z lat 1921 i 1931 mamy dość dobre informacje z pierwszych dziesięciu lat niepodległości. Można też przypuszczać, że w następnym okresie mogła w niektórych sprawach ulec poprawie. $Z$ zachowanych danych wynika, że niecałe $60 \%$ zabudowy to domy murowane, pozostałe to drewniane. Rozwijało się zarówno budownictwo wielorodzinne, jak i jednorodzinne. Na szczególne podkreślenie zasługuje działalność władz miasta z drugiej połowy lat 20., a nawet początków 30. Korzystając z lepszej koniunktury gospodarczej, wzniesiono pięć dużych budynków mieszkalnych (dzisiaj nazwalibyśmy je blokami komunalnymi), mających kilkadziesiąt, a w jednym przypadku nawet blisko 300 pomieszczeń. Łącznie było ich ponad 500. Rozwijało się też w tym czasie budownictwo indywidualne. Mimo to sytuacja nie była najlepsza. Według prasowych danych z roku 1938 aż około 40\% mieszkań było nadal jednoizbowych, mieszkała $w$ nich $w$ przybliżeniu nieco ponad jedna trzecia ludności trybunalskiego grodu. Prawie tyle samo było lokali dwuizbowych. Można więc wnioskować, że większość przedwojennych mieszkańców żyło w bardzo niedobrych warunkach mieszkaniowych, w ciasnocie, zwłaszcza że w takim jedno-, dwuizbowym lokalu mieszkało kilka osób, a w co piątym nawet sześć czy więcej. Taka sytuacja bardzo niekorzystnie wpływała na proces wychowania, a wszelkie konflikty rodzinne czy ewentualne negatywne postawy niektórych jej członków, choćby nawet sporadyczne nadużywanie alkoholu czy tylko palenie papierosów, w takiej ciasnocie urastało do rangi wielkiego problemu i mogło dezintegrować tę podstawową jednostkę społecznąa

9 A. Felchner, Zdrowie i zdrowotność..., dz. cyt., s. 29-42; K. Baranowski, Zabudowa i warunki mieszkaniowe w latach 1918-1939. W: Dzieje Piotrkowa Trybunalskiego, s. 398-405. Szerzej w sprawozdaniach ówczesnych władz, znajdujących się w Archiwum Państwowym w Piotrkowie Trybunalskim: Samorząd Piotrkowa Trybunalskiego w latach 1935-1939 (krótki zarys działalności), 
Sytuacja mieszkaniowa była szczególnie trudna dla dzieci, które nieraz nie miały nawet kąta do nauki. O ile nie dało się w sposób zdecydowany zmienić struktury lokali i usunąć nadmiernego zagęszczenia, to poprawie uległo wyposażenie znacznej części mieszkań, chociaż zmiany zaczęły następować dopiero pod koniec pierwszej dekady niepodległości. Od połowy lat 20. zaczęto budować sieć wodno-kanalizacyjną, która do 1939 roku objęła praktycznie tylko centralne rejony miasta, ale o największej ilości dużych kamienic. Z drugiej strony można przypuszczać, że w większości biedniejszych domów sanitariaty i kran były jedynie na podwórzu. Jeśli wodę czerpano ze studni, groziło zainfekowanie wszystkich mieszkańców bardzo ciężkimi chorobami przewodu pokarmowego - durem brzusznym, czerwonką, ostrymi biegunkami. W Piotrkowie Trybunalskim dość często odnotowywano przypadki pierwszej z wymienionych chorób. W 1923 roku w Piotrkowie Trybunalskim i w powiecie stwierdzono 125 przypadków duru brzusznego, w 1928 roku w mieście było 26 zachorowań, a na terenie powiatu 60 . Podobnie było aż do wybuchu wojny. Jedynym pozytywem była zmniejszająca się śmiertelność. W wypadku takich mieszkań nie chodzi tylko o to, że dzieci i młodzież nie miały warunków do nauki i wypoczynku, ale także że były trudności z utrzymaniem higieny. Największe zagrożenie sprawiały choroby zakaźne przenoszone drogą kropelkową, przez kontakt lub przez insekty. Nawet zwykłe banalne przeziębienie, kaszel czy katar, w takich warunkach błyskawicznie przenosił się na innych współmieszkańców. Pamiętajmy też, że w Piotrkowie, podobnie jak w całym kraju, występowały też z różnym nasileniem takie groźne choroby, jak błonica, płonica, odra, choroba oczu - jaglica czy dur osutkowy (zwany dawniej tyfusem plamistym). Najgroźniejszą jednak niewątpliwie była gruźlica ${ }^{10}$. Lata międzywojenne to próby poszukiwania skutecznych metod walki z tą ostatnią chorobą. Zaczęto wprowadzać szczepienia ochronne, ale jeszcze na niewielką skalę. Na tę chorobę w 1923 roku zmarło w mieście i powiecie 111 osób, pięć lat później tylko na terenie powiatu - 135. W 1934 roku tylko w piotrkowskiej Ubezpieczalni Społecznej było zarejestrowanych 315 chorych na gruźlicę, $60 \mathrm{z}$ nich skierowano do leczenia szpitalnego, a 12 wysłano do sanatoriów przeciwgruźliczych. W kolejnym roku stwierdzono 216 nowych zachorowań wśród ubezpieczonych. Działania te obejmo-

1939, Piotrków Trybunalski; Sprawozdanie Magistratu m. Piotrkowa od roku 1925-1928, 1928, Piotrków Trybunalski; Sprawozdanie samorządu miejskiego miasta Piotrkowa za lata 1925-1933, 1933, Piotrków Trybunalski.

10 A. Felchner, 1998, Sytuacja zdrowotna ludności powiatu piotrkowskiego w pierwszych latach II Rzeczypospolitej. „Piotrkowskie Zeszyty Historyczne”, t. I, s. 59-74; tenże, Zdrowie i zdrowotność, s. 117-141; tenże, 2001, Z problematyki zwalczania chorób zakaźnych $w$ Piotrkowie i $w$ powiecie piotrkowskim w latach 1919-1921 - zagadnienia medyczne i społeczne, W: B. Płonka-Syroka (red.), Studia z Dziejów Kultury Medycznej, t. IV, Choroba, jako zjawisko społeczne i historyczne. Wrocław, s. $212-220$. 
wały tylko część pracowników, często żyjących w lepszych warunkach, a mimo to choroba ta powodowała tak duże spustoszenie. Można tu dodać, że w Piotrkowie Trybunalskim działał jeden z ponad 60 oddziałów Ubezpieczalni Społecznych (wcześniej, w latach 1920-1933 istniały Kasy Chorych). Prowadził on, podobnie jak inne, szeroką akcję leczniczą oraz profilaktyczną, między innymi wspomniane szczepienia przeciwko gruźlicy. Dysponował też własnym, niewielkim, niespełna stułóżkowym szpitalem (jednym z trzech na terenie województwa łódzkiego). W 1938 roku w innej ogólnodostępnej piotrkowskiej przychodni przeciwgruźliczej było w ewidencji od 1300 do ponad 1400 pacjentów, w tym ponad 200 dzieci. Oczywiście czynną gruźlicę miało tylko kilkuset z nich, ale jednocześnie w każdym kwartale umierało z jej powodu po kilkunastu chorych. Niewątpliwie istotną rolę $\mathrm{w}$ rozprzestrzenianiu się tej choroby odgrywały wspomniane nie najlepsze warunki mieszkaniowe, znacznie ułatwiające rozprzestrzenianie się tej choroby. Inną, mniej groźną, ale mogącą doprowadzić nawet do utraty wzroku, była jaglica, zupełnie obecnie w Polsce nieznana. Gdy w 1927 roku uruchomiono w Piotrkowie Trybunalskim specjalistyczną przychodnię przeciwjagliczą, to w pierwszym roku działalności zgłosiło się do niej prawie tysiąc osób, ale tę chorobę rozpoznano na szczęście tylko u kilkunastu procent $\mathrm{z}$ nich. Jednak już na początku lat 30., gdy zaczęto robić przeglądy między innymi w szkołach, a także badać pod tym kątem poborowych, a więc znacznie poszerzono krąg osób, obligatoryjnie będących w polu zainteresowań tej przychodni, w ciągu roku leczono około 2 tys. osób, w dużej mierze uczniów. Do tych działań dołączała też miejscowa Ubezpieczalnia Społeczna, która prowadziła działalność zarówno leczniczą, jak i profilaktyczną, obejmującą również inne choroby społeczne. W wypadku jaglicy ta choroba była oznaką trudnych warunków mieszkaniowych, braku nawyków, a także zachowań higienicznych. Polegały one choćby na używaniu przez wszystkich domowników wspólnych, rzadko zmienianych ręczników czy niezbyt częstej zmiany pościeli, zwłaszcza że wiele dzieci sypiało razem we wspólnych łóżkach. Takie problemy zdrowotne, prowadzące nieraz do kalectwa, a w wypadku gruźlicy śmierci kogoś bliskiego, wpływały bardzo negatywnie na wszystkich, prowadziły do obniżenia statusu społecznego poszczególnych rodzin, negatywnie wpływały na proces wychowania $^{11}$.

11 Tamże, a także: A. Felchner, 2007, Rozwój medycyny szkolnej w Piotrkowie Trybunalskim i powiecie piotrkowskim w II Rzeczypospolitej. „Archiwum Historii i Filozofii Medycyny”, t. 70, s. 86-91; B. Wachowska, Stosunki społeczne w latach 1918-1939. W: Dzieje Piotrkowa Trybunalskiego, s. 423-425; patrz też wymienione w przypisie 9 oficjalne sprawozdania miejscowych władz. W piotrkowskim Archiwum zachowało się również bardzo dużo dokumentów archiwalnych, dotyczących warunków życia i zdrowia mieszkańców miasta i powiatu piotrkowskiego w okresie międzywojennym, zwłaszcza w trzech zespołach: Akta miasta Piotrkowa 1746-1945; Starostwo Powiatowe Piotrkowskie 1919-1939 oraz Wydział Powiatowy w Piotrkowie Trybunalskim 1917-1947. 
Istotną rolę odgrywa też samo zrozumienie zachowań prozdrowotnych w społeczeństwie - od poziomu higieny osobistej do świadomej dbałości o właściwy poziom $w$ tym względzie $\mathrm{w}$ domu i zagrodzie. Odpowiednia postawa wyraża się też $\mathrm{w}$ dążeniach do ewentualnego tworzenia i rozwoju różnych instytucji, akcji, urządzeń wpływających na zdrowotność. W ówczesnym społeczeństwie II Rzeczypospolitej taka prozdrowotna świadomość była na ogół niezbyt wysoka, mimo dużych wysiłków różnych instytucji i władz. Wpływała ona niewątpliwie na szeroko pojętą higienę oraz na szereg różnych innych, związanych $\mathrm{z}$ tą kwestią zachowań. W dostępnych piotrkowskich dokumentach archiwalnych, w oficjalnych sprawozdaniach czy w różnych innych materiałach nie znalazłem na przykład informacji o konieczności codziennej kąpieli rano i wieczorem czy częstej zmianie bielizny, będących podstawą osobistej higieny. Łazienki z bieżącą wodą zaczęły się pojawiać $\mathrm{w}$ mieście zapewne dopiero $\mathrm{w}$ drugiej połowie lat 20. ubiegłego wieku, od momentu rozpoczęcia budowy sieci wodno-kanalizacyjnej. Prawdopodobnie znajdowały się jedynie w lokalach najzamożniejszych rodzin, głównie w centrum, $\mathrm{w}$ najlepiej wyposażonych domach. $\mathrm{Z}$ tego powodu w mieście, a także w obydwu mniejszych miasteczkach, istniały publiczne łaźnie. Lokalne władze, w tym oświatowe, widziały wprawdzie potrzeby wyrobienia w uczniach nawyków higienicznych. Zdawano sobie doskonale sprawę, że brak czystości sprzyja rozwojowi różnych chorób. Dlatego też obowiązkowo każda piotrkowska klasa szkolna okresowo szła do łaźni. Kąpiel była opłacana przez miasto. Odbywało się to jednak zaledwie raz na kilka tygodni. Można przypuszczać z dużą dozą prawdopodobieństwa, że być może dla większości uczniów była to jedyna kąpiel, a na co dzień poprzestawano na dość pobieżnym myciu się, na przykład w misce. O takich działaniach na terenie powiatu piotrkowskiego brak informacji, nikt wówczas nie przewidywał budowy tam sieci wodno-kanalizacyjnej. Nastąpiło to dopiero w przybliżeniu pół wieku później. Pokazuje to również, jak olbrzymi skok cywilizacyjny dokonał się w naszym społeczeństwie w ubiegłym wieku. W sprawozdaniu z jednej ze wsi skierowana tam do pracy pielęgniarka pisała w 1937 roku, że miejscowe stawy i strumyki były jedynymi miejscami kąpieli. Gdy więc temperatura spadała lub panował mróz, od pierwszych chłodów jesienią do wiosennego ocieplenia, blisko pół roku, mieszkańcy nie kąpali się. Zresztą mycia się pod prysznicem czy w wannie nie można porównać do letniej kąpieli w rzece lub jeziorze. Również stan higieny ich pomieszczeń mieszkalnych i gospodarczych pozostawiał wiele do życzenia,

Z nich pochodzą przytaczane dane szczegółowe. Szerzej na temat Ubezpieczalni Społecznych: J. Sadowska, 2006, Świadczenia lecznicze w Ubezpieczalniach Społecznych w Polsce (1933-1951). Łódź. Dane ogólnopolskie, pokazujące różne formy działalności władz państwowych w obszarze zdrowia, bardzo dobrze ilustruje opracowanie: Dwadzieścia lat publicznej służby zdrowia w Polsce Odrodzonej 1918-1939, 1939, wstęp E. Piestrzyński, Warszawa. 
podobnie jak w większości wsi tego powiatu. Jedno-, dwuizbowe chaty bez wygód, niewietrzone, pomieszczenia mieszkalne stykające się bezpośrednio z oborą czy chlewnią, wspólne łóżka, małe okna, zimą nieotwierane - taki stan sprzyjał szerzeniu się różnych chorób. Dbanie o czystość ciała polegała tam głównie na przepłukaniu rąk czy twarzy wodą. Brak dbałości o higienę szczególnie negatywnie odbijał się na uzębieniu. Często dopiero w szkole, nie tylko na wsi, ale także w mieście, uczniowie dostawali szczoteczki do zębów i uczyli się je wykorzystywać. Efektem była powszechnie panująca próchnica. Sytuacja taka, jak świadczą różne badania, była również w innych częściach kraju, zarówno na wschód - na Lubelszczyźnie, jak i na zachód, w Wielkopolsce, $\mathrm{z}$ tą jednak różnicą, że wsie dawnego zaboru pruskiego (niemieckiego od 1871 roku) posiadały na ogół murowane domy. Nie było też tam analfabetyzmu, przez co i świadomość prozdrowotna była wyższa. Można więc stwierdzić, że Piotrków i powiat piotrkowski mogą być dobrą ilustracją sytuacji większości terytorium II Rzeczypospolitej ${ }^{12}$.

Odrębnym zagadnieniem, wpływającym pozytywnie na ogólnie pojęte wychowanie, a zwłaszcza poprawę zdrowotności uczniów, był zorganizowany letni wypoczynek, potocznie zwany koloniami. Zaczęto je organizować na ziemiach polskich jeszcze pod koniec XIX wieku. Taki wyjazd był bardzo korzystny, zwłaszcza $\mathrm{w}$ istniejącej i przedstawionej powyżej sytuacji mieszkaniowej oraz zdrowotnej. Pozwalał uczniom choć na krótko zamieszkać w lepszych warunkach, w zdrowszej okolicy. Z dokumentów wynika też, że takimi akcjami objęci byli tylko uczniowie szkół piotrkowskich, nie dotyczyła ona liczniejszej grupy dzieci ze wsi i małych miasteczek. Brak w zachowanych, znanych mi dokumentach, śladów działalności na tym polu piotrkowskiej Ubezpieczalni Społecznej. Wiadomo, że ta instytucja, różne jej oddziały w całej Polsce, też wysyłała dzieci osób ubezpieczonych na wypoczynek. Mogli się tam również znaleźć uczniowie spoza Piotrkowa. Wszyscy koloniści byli odpowiednio, regularnie żywieni, a ich stan zdrowia podlegał kontroli lekarskiej. Mieli też możliwość wyjechać poza swoją miejscowość, trochę lepiej poznać bliższą i dalszą okolicę. Trzeba dodać, że wówczas w większości ograniczano się jednak do umieszczania dzieci w stosunkowo niedużej odległości od domu, w budynkach znajdujących się często w suchym sosnowym lesie, blisko jakiejś rzeczki czy zbiornika wodnego, poza zwartą zabudową wiejską.

${ }^{12}$ Odsyłam do literatury z przypisu nr 11 oraz do innych opracowań na przykład: J. Majchrzyk-Mikuła, 2013, Higiena szkolna na Lubelszczyźnie w latach 1918-1939 na tle całego kraju. Piotrków Trybunalski (szczególnie do rozdziałów 1 i 3); M. Okrasa, 2017, Bursy i internaty szkolne w województwie lubelskim w latach 1918-1998. Lublin (zwłaszcza do podrozdziałów mówiących o warunkach życiowych młodzieży szkolnej); a także do pracy zbiorowej Zdrowie i edukacja prozdrowotna społeczeństwa polskiego na przestrzeni XIX $i$ XX wieku. Wybrane aspekty, 2007, red. M. Posłuszna, Poznań (po dwa artykuły M. Posłusznej oraz W. Wrześniewskiego dotyczących sytuacji bytowych, w tym zdrowotnych dzieci i młodzieży wiejskiej). 
Młodzi piotrkowianie byli nieraz wysyłani do miejsc nad odległą o kilkanaście kilometrów Pilicą. W niektórych, raczej nielicznych wypadkach, jedynie dzieci ubezpieczonych korzystały z ośrodków w górach czy nad morzem. Decydowały o tym względy finansowe, które nie pozwalały na dalekie podróże i znaczącą zmianę klimatu. Można tu posłużyć się cytatem $\mathrm{z}$ jednego $\mathrm{z}$ wspomnianych urzędowych sprawozdań piotrkowskich władz, gdzie bez żadnych przemilczeń, jasno i dobitnie określano istniejącą bardzo trudną sytuację społeczną w latach wielkiego kryzysu. W materiałach tych, obrazujących sytuację z 1933 roku, a więc z końcowego okresu wielkiego kryzysu, pisano: „Zubożenie szerokich mas ludności, głód i chłód goszczący w ich izbach oraz ciężka walka o kawałek suchego chleba najdotkliwiej odbijają się na siłach i zdrowiu ich dzieci, przekształcając je w element chuderlawy, podatny na wszelkiego rodzaju choroby, zwłaszcza gruźlicę. Również często okropne warunki mieszkaniowe, w jakich dzieci przebywają przygotowują grunt dla tych chorób [...]. Magistrat na tym odcinku swej pracy postanowił przeprowadzić na szeroką skalę akcję zapobiegawczą pod postacią kolonii letnich i dożywiania dzieci"13. Można więc stwierdzić, że mimo wielkich starań różnych władz, a zapewne i samych rodziców, ta forma pomocy, głównie z powodów finansowych, ekonomicznych, tylko częściowo mogła się rozwijać, a jej różnorodne, pozytywne oddziaływania (w tym wychowawcze) nie mogły być realizowane w skali odpowiadającej potrzebom.

Istotną rolę odgrywa też w procesie wychowania, zwłaszcza najmłodszych, zabawa. W zaprezentowanych powyżej warunkach trudno o niej mówić w mieszkaniach zajmowanych przez większości rodzin czy na ciasnych podwórkach, zarówno w samym Piotrkowie, jak i na terenie powiatu. Istotne jest też stworzenie dla starszych dzieci oraz dla młodzieży warunków uprawiania sportu, a przynajmniej - dla wszystkich zapewnienie niezbędnego ruch. Dlatego też istotne były dla takiego właściwego wychowania, zarówno z punktu widzenia pedagogów, jak i lekarzy, niektóre działania w tym kierunku władz miejskich. Jeszcze w czasie I wojny światowej, pod rządami austrowęgierskimi, utworzono na końcu jednej

${ }^{13}$ Sprawozdanie samorzadu miejskiego..., dz. cyt., s. 57. Niemal taki sam cytat znajduje się też w mojej monografii Zdrowie i zdrowotność..., dz. cyt., s. 94-95, tam również opisano cała procedurę kwalifikowania na taki wypoczynek. Brano pod uwagę zarówno stan zdrowia, dlatego wszyscy uczniowie byli skrupulatnie badani przez lekarzy, jak i zamożność rodziców. Ogółem przez osiem lat, w okresie 1925-1932, na kolonie wysłano 1676 najuboższych uczniów z Piotrkowa Trybunalskiego, - bo na tyle wystarczyło różnorodnych funduszy, pochodzących z kilku źródeł, zarówno z publicznych zbiórek, jak i z dofinansowania władz państwowych. O tym jak te działania były potrzebne, świadczy fakt, że piotrkowski samorząd uważał, że powinno się wysyłać rocznie około 3 tys. dzieci, jednak nie było na to środków finansowych. Osobne kolonie mieli uczniowie pochodzenia żydowskiego, gdyż musiały mieć specjalne, koszerne posiłki, tamże. Działalności na tym polu Ubezpieczalni Społecznej opisała J. Sadowska, s. 67-68. 
z najbardziej reprezentacyjnych ulic Piotrkowa - obecnej 3 Maja - park miejski. Przez cały okres międzywojenny dbano o niego, upiększano, a także zorganizowano na jego obrzeżach ogród botaniczny. Służył on nie tylko spacerowiczom, ale i dzieciom oraz młodzieży szkolnej jako pomoc dydaktyczna, sprzyjał również wychowaniu proekologicznemu, a także zachęcał rodziny do wspólnych spacerów. Dla najmłodszych, w pobliżu wznoszonych komunalnych budynków przy aktualnej ulicy Sulejowskiej, utworzono pierwszy ogródek jordanowski. W ostatnich przedwojennych latach w lokalnej prasie informowano o budowie kolejnych. Obecnie trudno jednak stwierdzić, na ile te plany zostały zrealizowane. Dla nieco starszych oraz dla wszystkich chcących uprawiać różnorodne dyscypliny sportu w pobliżu parku, zbudowano cały kompleks sportowy z różnymi boiskami, bieżnią, kortami tenisowymi, odkrytą pływalnią. Warto też wspomnieć, że pod miastem, blisko szosy do Radomska, znajdowało się, istniejące do dziś, trawiaste lotnisko, działał też Aeroklub Piotrkowski. Inną instytucją sprzyjającą rekreacji, a także zapewne pozytywnie wpływającą na poziom żywienia, były ogródki działkowe. Utworzono ich w sumie kilka w różnych częściach miasta. Można więc stwierdzić, że w tym stosunkowo krótkim, kilkunastoletnim okresie pokoju między wojnami o niepodległość i granice a wybuchem II wojny światowej w około pięćdziesięciotysięcznym mieście stworzono kilka ważnych placówek mających wpływ na właściwe wychowanie, zwłaszcza zdrowotne, fizyczne. Następowało to mimo kryzysów i wspomnianych trudności finansowych, niewątpliwie z wielką korzyścią, zwłaszcza dla dzieci i młodzieży ${ }^{14}$.

Wspomniane powyżej różne czynniki, głównie ekonomiczne, miały też bardzo duży wpływ na inny ważny element zawsze służący prawidłowemu rozwojowi dzieci i młodzieży - odpowiednie odżywianie. Trudno przecież mówić o czymkolwiek: o nauce, zabawie, właściwemu oddziaływaniu wychowawczemu, gdy nasz wychowanek pragnie tylko jednego - zaspokoić głód. W okresie międzywojennym, właśnie z powodów ekonomicznych, wiele dzieci było niedożywionych lub niewłaściwie odżywianych. Nieprawidłowe żywienie - czyli w tym wypadku: mała ilość posiłków ze zbyt dużymi przerwami między nimi, niedożywienie jakościowe i ilościowe - powoduje nie tylko wiele chorób, ale utrudnia również proces uczenia, pogarszają nastrój i samopoczucie, czynią taką osobę apatyczną, bez inicjatywy. Ograniczają więc w znacznym stopniu, a nieraz nawet uniemożliwiają, wszelkie działania wychowawcze. Długotrwałe niedożywianie najmłodszych może doprowadzić do nieodwracalnych zmian w organizmie, znacznie zmniejszać odporność

${ }^{14}$ Wszelkie szczegóły zawarte są w przytaczanych wcześniej przedwojennych sprawozdaniach władz Piotrkowa Trybunalskiego, które jak najbardziej słusznie chwaliły się tymi liczącymi się osiągnięciami. Warto też sięgnąć do współczesnych źródeł informacji - stron internetowych wspomnianych w większości działających do dziś instytucji. 
na różne infekcje, osłabiając na przykład proces wzrostu. Starsze dzieci i młodzież powinny spożywać cztery posiłki, co cztery godziny codziennie, składające się z nie mniej niż czterech grup produktów. Chłopcy w okresie intensywnego rozwoju fizycznego (13-18 lat) powinni dostarczać swojemu organizmowi od ponad 2,5 tys. kalorii do nawet prawie 4 tys. przy dużym zapotrzebowaniu oraz wysiłku. Dziewczęta w tym samym wieku mają trochę niższe potrzeby - od ponad 2 tys. do prawie 3 tys. W skład diety powinny wchodzić produkty zbożowe, warzywa i owoce, mleko i przetwory mleczne, różnorodne mięso, jajka, a także tłuszcze. Równie ważne jest zachowanie bilansu wody - około półtora litra różnych wartościowych płynów. Takie są współczesne wskazania żywieniowe ${ }^{15}$.

W okresie międzywojennym właściwe do rozwoju młodych organizmów normy żywieniowe w większości przypadków nie były zachowywane. $Z$ dokumentów archiwalnych i innych materiałów wynika, że był to problem ogólnopolski. Można tu powołać się na interesujące badania przeprowadzone w połowie lat 30. wśród mieszkańców Krakowa ${ }^{16}$. Zgodnie z nimi okazało się, że jedynie w najbogatszych rodzinach (w przybliżeniu nieco ponad jednej czwartej badanych) dostatecznie odżywiano się, a niekiedy nawet spożywano więcej, niż wskazywały to normy. Tutaj jadłospis był najbogatszy i bardzo różnorodny. Zawierał zarówno pieczywo, jak i warzywa czy mięso, którego tu zjadano najwięcej i codziennie. Nie zawsze jednak odżywiano się prawidłowo. W grupie średniozamożnej (niżsi urzędnicy, rzemieślnicy, podoficerowie, najlepiej sytuowani robotnicy, ponad połowa badanych) jedzenie zwykle dostarczało odpowiednią liczbę kalorii, ale wielu odżywiało się skromniej. Tutaj też w jadłospisach znajdowały się najtańsze, najbardziej popularne warzywa czy niezbyt drogie gatunki nabiału, mięsa i ich przetworów. Owoce pojawiały się nie we wszystkich domach i przeważnie tylko w sezonie. Wśród najuboższych (głównie robotnicy) była spora grupa osób (ponad połowa), której pożywienie dostarczało poniżej 3 tys. kalorii, a w ponad 10\% - nawet mniej niż 2 tys. kalorii - a więc znacznie poniżej jakichkolwiek normy. W jadłospisie mięso występowało wśród tych osób w większej ilości sporadycznie, zapewne też jadłospis był bardzo ograniczony - do najtańszych produktów. Można przypuszczać,

${ }_{15}$ B. Wojnarowska i in., Biomedyczne podstawy..., dz. cyt., , s. 188-201.

${ }_{16}$ M. Steinbach, 1937, W sprawie odżywiania ludności miasta Krakowa, Wilno. Były to szerokie badania ankietowe i przez to bardzo wiarygodne. Objęto nimi grupę uczniów z 51 szkół powszechnych i średnich, łącznie 1167 rodzin i 6626 osób. Najmniej badanych pochodziło z rodzin robotniczych, osób najmniej wykształconych, nie dotarto prawdopodobnie do środowisk dłuższy czas bezrobotnych. Zresztą prawdopodobnie młodzież z tego ostatniego środowiska, głównie z przyczyn finansowych, tylko wyjątkowo trafiała do szkół średnich, nie była więc badana. Przedstawione wyniki ankietyzacji mogły być zapewne nieco lepsze, bardziej optymistyczne niż w rzeczywistości. Potwierdzają to badania z końca ubiegłego stulecia: W. Szewczyk, 1991, Spożycie żywność w Polsce w okresie międzywojennym (na tle dochodów i wydatków na konsumpcję), Warszawa. 
że w grupie bezrobotnych sytuacja była jeszcze gorsza, a więc było to chroniczne niedożywienie wszystkich członków tych rodzin ${ }^{17}$. W Piotrkowie Trybunalskim nie przeprowadzono takich badań, ale można przypuszczać, że zdecydowana większość mieszkańców lokowała się w grupie drugiej lub trzeciej i odżywiała się dość skromnie, czasami poniżej norm. Wśród bezrobotnych sytuacja była zapewne identyczna jak w Krakowie, a niedożywienie chroniczne. Dlatego też władze miejskie organizowały dożywianie w szkołach. Ponadto z okazji świąt, na przykład na Boże Narodzenie, rozdawano dzieciom żywność. Znajdowały się w nich nie tylko słodycze, ale i kiełbasa, pszenne pieczywo czy cukier - a więc podstawowe, niezbędne produkty. Każda z paczek miała od ponad dwóch do nawet 5 kilogramów. O skali potrzeb świadczy fakt, że takimi akcjami obejmowano w latach 1925-1928 - a więc w okresie względnego rozwoju gospodarczego, przed wielkim kryzysem - nawet ponad 1300 dzieci, a później, w czasie kryzysu, nawet ponad 1700 dzieci. Jeszcze gorsza sytuacja panowała na wsi, gdzie, jak świadczą dokumenty, w większości wypadków podstawowym produktem były ziemniaki, niemal bez tłuszczu, a mleko, które starano się sprzedać na targu, dzieci otrzymywały w niewielkich ilościach. Trudności były nawet $\mathrm{z}$ chlebem, bo na przednówku, a więc wczesną wiosną, zaczynało już brakować u wielu biedniejszych rolników nawet mąki. Mięso jadano sporadycznie, głównie na święta ${ }^{18}$. Można stwierdzić, że spora część dzieci i młodzieży w samym Piotrkowie, a w okresie kryzysu zapewne większość, na wsi zaś, wśród rodzin chłopskich, poza najbogatszymi, niemal wszyscy, była niedożywiona. Zauważają to i podkreślają w sprawozdaniach również lekarze podczas badań okresowych. W takiej sytuacji wszelkie działalności wychowawcze, na przykład w szkołach, były bardzo utrudnione.

Podsumowując, w okresie II Rzeczypospolitej, w latach 1918-1939, w wielu wypadkach sytuacja dzieci i młodzieży szkolnej była bardzo trudna. Na pierwszy plan wysuwają się przede wszystkim złe warunki mieszkaniowe oraz trudności żywieniowe. Wynikały one z ogólnego niedostatku całego społeczeństwa, zapóźnień cywilizacyjnych, słabości młodego państwa, przeżywającego różnorodne kryzysy. W takiej sytuacji wszelka działalność wychowawcza musiała napotykać na duże trudności. Te problemy są zauważane w wielu publikacjach, ale należy, moim zdaniem, zwrócić na nie większą uwagę przy omawianiu problemów polskiej oświaty i wychowania w okresie dwudziestolecia, między I a II wojną światową.

${ }^{17}$ M. Steinbach, dz. cyt., s. 4-30.

${ }_{18}$ Sprawozdanie Magistratu..., dz. cyt., s. 14; Sprawozdanie samorządu miejskiego..., dz. cyt., s. 59. A. Felchner, Zdrowie i zdrowotność..., dz. cyt., s. 63-68. 


\section{LITERATURA}

\section{WYDAWNICTWA ŹRÓDŁOWE}

Dwadzieścia lat publicznej służby zdrowia w Polsce Odrodzonej 1918-1939, 1939, wstęp E. Piestrzyński. Warszawa.

Mały Rocznik Statystyczny Polski wrzesień 1939-czerwiec 1941, 1941, Londyn.

Samorząd Piotrkowa Trybunalskiego w latach 1935-1939 (krótki zarys działalności), 1939, Piotrków Trybunalski.

Sprawozdanie Magistratu m. Piotrkowa od roku 1925-1928, 1928, Piotrków Trybunalski. Sprawozdanie samorzadu miejskiego miasta Piotrkowa za lata 1925-1933, 1933, Piotrków Trybunalski.

Wiek XX w źródłach. Wybór tekstów źródłowych z propozycjami metodycznymi dla nauczycieli historii, studentów i uczniów, 1998, opr. M. Sobańska-Bondaruk, S.B. Lenard. Warszawa.

\section{OPRACOWANIA ZWARTE I ARTYKUŁY}

Baranowski B. (red.), 1989, Dzieje Piotrkowa Trybunalskiego. Łódź.

Baranowski K., 1989, Zabudowa i warunki mieszkaniowe w latach 1918-1939. W: B. Baranowskiego (red.), Dzieje Piotrkowa Trybunalskiego. Łódź.

Cameron R., 1997, Historia gospodarcza świata. Od paleolitu do czasów najnowszych, wyd. II. Warszawa.

Felchner A., 1998, Sytuacja zdrowotna ludności powiatu piotrkowskiego w pierwszych latach II Rzeczypospolitej. „Piotrkowskie Zeszyty Historyczne”, t. I.

Felchner A., 2001, Z problematyki zwalczania chorób zakaźnych $w$ Piotrkowie i $w$ powiecie piotrkowskim w latach 1919-1921 - zagadnienia medyczne i społeczne. W: B. Płonka-Syroka (red.), Studia z Dziejów Kultury Medycznej, t. IV, Choroba, jako zjawisko społeczne i historyczne. Wrocław.

Felchner A., 2006, Zdrowie i zdrowotność Piotrkowian. Z problematyki zdrowotności mieszkańców Piotrkowa Trybunalskiego i powiatu piotrkowskiego na tle całego kraju (od końca lat 20-tych do początków 70-tych XX wieku). Wrocław.

Felchner A., 2007, Rozwój medycyny szkolnej w Piotrkowie Trybunalskim i powiecie piotrkowskim w II Rzeczypospolitej. „Archiwum Historii i Filozofii Medycyny”, t. 70.

Majchrzyk-Mikuła J., 2013, Higiena szkolna na Lubelszczyźnie w latach 1918-1939 na tle całego kraju. Piotrków Trybunalski.

Okrasa M., 2017, Bursy i internaty szkolne w województwie lubelskim w latach 19181998. Lublin. 
Piasta A., 2007, Piotrków Trybunalski w latach pierwszej wojny światowej. Piotrków Trybunalski.

Popiński K., 2010, Finansowe uwarunkowania rozwoju polskiego potencjału militarnego w latach 1936-1939. W: T. Głowiński i K. Popiński (red.), Gospodarka i społeczeństwo a wojskowość na ziemiach polskich, Wrocław.

Posłuszna M. (red.), 2007, Zdrowie i edukacja prozdrowotna społeczeństwa polskiego na przestrzeni XIX i XX wieku. Wybrane aspekty. Poznań.

Sadowska J., 2006, Świadczenia lecznicze w Ubezpieczalniach Społecznych w Polsce (1933-1951). Łódź.

Skodlarski J., 2000, Zarys historii gospodarczej Polski. Warszawa, Łódź.

Steinbach M., 1937, W sprawie odżywiania ludności miasta Krakowa. Wilno.

Szewczyk W., 1991, Spożycie żywność $w$ Polsce $w$ okresie międzywojennym (na tle dochodów i wydatków na konsumpcję). Warszawa.

Szpak J., 1997, Historia gospodarcza powszechna. Warszawa.

Tomaszewski J., Landau Z., 2005, Polska w Europie i świecie 1918-1939. Warszawa.

Wachowska B., 1989, Stosunki społeczne w latach 1918-1939. W: B. Baranowskiego (red.), Dzieje Piotrkowa Trybunalskiego. Łódź.

Włodarski Z., Hankała A., 2004, Nauczanie i wychowanie jako stymulacja rozwoju człowieka. Podręcznik dla studentów szkół pedagogicznych i nauczycieli. Warszawa, Kraków. Wojnarowska B., Kowalewska A., Izdebski Z., Komosińska K., 2010, Biomedyczne podstawy kształcenia i wychowania. Podręcznik akademicki. Warszawa.

THE INFLUENCE OF SOCIAL, ECONOMIC AND HEALTH SITUATION ON PUPILS' EDUCATION IN THE SECOND REPUBLIC OF POLAND ON THE EXAMPLE OF PIOTRKÓW TRYBUNALSKI AND PIOTRKÓW DISTRICT

\begin{abstract}
As a result of numerous factors, including activity of the whole generations of the Poles, in autumn 1918 Poland regained its independence. Unfortunately, the economic and health situation in the country was very bad. Between 1918 and 1939 numerous changes took place. In spite of this, during the whole period, the residential and nutritional position of the society was still unsatisfactory. Obviously, it influenced in a negative way mostly children and the youth. A good example of the discussed issue can be Piotrków Trybunalski and its district. Many dwellers of the town lived in single- or two-room flats, mostly without the connection to water and sewage system. The majority of children was insufficiently fed or frequently malnourished. Even worse situation was in Piotrków district, especially in villages. One needs to pay attention to those complicated but meaningful issues while discussing the education and upbringing of children and the youth in Poland, between World War I and World War II.
\end{abstract}

Keywords: Poland 1918-1939, Piotrków Trybunalski and piotrkow district, education, children, health 